\title{
THE INFLUENCE OF COMPENSATION, ORGANIZATION CULTURE AND MOTIVATION ON EMPLOYEE PERFORMANCE
}

\author{
KAREL TJAHJADI \\ MELIANTHA SANJUNG URIA \\ Trisakti School of Management, Jl. Kyai Tapa No. 20, Jakarta, Indoensia \\ kareltjahjadi@yahoo.com, Meliantha48@gmail.com
}

\begin{abstract}
The purpose of this study was to analyze and determine the effect of compensation, organizational culture and motivation on employee performance at PT. Perfect Circle Engineering. This study takes a population that is an employee at PT. Perfect Circle Engineering. The sampling method used is non-probability sampling method in the form of purposive sampling. In collecting data, researchers distributed questionnaires to respondents and the samples obtained in this study were 59 questionnaires. The tool used to analyze data is the multiple regression method. The results obtained from this study are the compensation and motivation variables individually affect the performance of employees while the organizational culture individually does not affect the performance of employees.
\end{abstract}

Keywords: Compensation, Organizational Culture, Motivation, Employee Performance

Abstrak: Penelitian bertujuan untuk menganalisis dan mengetahui pengaruh kompensasi, budaya organisasi dan motivasi terhadap kinerja karyawan pada PT. Perfect Circle Engineering. Penelitian ini mengambil populasi yang merupakan karyawan pada PT. Perfect Circle Engineering. Metode pengambilan sampel yang digunakan adalah metode non-probability sampling berupa purposive sampling. Dalam pengumpulan data, peneliti membagikan kuesioner kepada responden dan sampel yang diperoleh pada penelitian ini adalah sebanyak 59 kuesioner. Alat uji yang digunakan untuk menganalisis data adalah metode regresi berganda. Hasil yang diperoleh dari penelitian ini adalah variabel kompensasi dan motivasi secara individual berpengaruh terhadap kinerja karyawan sedangkan budaya organisasi secara individual tidak berpengaruh terhadap kinerja karyawan.

Kata kunci: Kompensasi, Budaya Organisasi, Motivasi, Kinerja Karyawan.

\section{INTRODUCTION}

Currently technology is developing very rapidly and there are a lot of electronic devices such as smartphones, smartwatches, laptops, tablets, ipads, and so on that require electricity to function properly. The source of electricity in Indonesia is managed by PT. State Electricity Company (Persero) or abbreviated as PT. PLN (Persero). Based on the Electricity Provider
General Plan (RUPTL) issued by PT. PLN, additional transmission networks and the required substation capacity are decreasing. In 2018-2027, there was an additional decrease in the transmission network of $3,772 \mathrm{kms}$ and substations of 13,807 MVA compared to the 2017-2026 RUPTL and in 2019-2028 there was a decrease of $6,562 \mathrm{kms}$ and 27,083 MVA compared to 2018-2027. The decrease in the need for transmission networks and the capacity 
of substations can lead to fewer projects available. These projects are carried out by companies that focus on electricity projects.

PT. Perfect Circle Engineering or abbreviated as Percie is a company engaged in EPC (Engineering, Producement and Construction) with a special focus on electricity. PT. Perfect Circle Engineering is located at Twink Center 8th floor, Jalan Kapten P. Tandean No. 82, RT.05 / RW. 01, Mampang Prapatan, South Jakarta. This company has products in the form of extra high voltage substation project, very high voltage substation project, medium voltage substation project, isolated gas substation project, transmission project, underground cable project, submarine cable project. PT. Perfect Circle Engineering has several experiences including: construction of an extra high voltage $500 \mathrm{kV}$ Deltamas Extension (Cibatu Baru) substation, construction of a $500 \mathrm{kV}$ Lekong extra high voltage substation, construction of transmission lines at 87 points of the Tanjung Jati - Ungaran - Pedan section, construction of a line air extra high voltage $500 \mathrm{kV}$ Bojonegara - Suralaya, construction of a $150 \mathrm{kV}$ Muara Karang - Angke high power cable line and many other experiences.

As a company engaged in electricity construction, of course there are many other companies engaged in the same field and are competing for the available electricity development projects. In order not to lose to its competitors and get existing projects, PT. Perfect Circle Engineering must improve the services provided to be of higher quality, to create a healthy and safe environment and to complete projects on time.

This service improvement can be carried out by employees whose work results are called employee performance. Companies can improve employee performance by paying attention to aspects of human resources such as compensation, organizational culture and motivation so that PT. Perfect Circle Engineering needs to pay attention to these aspects so that employees are able to perform optimally and productively.

Performance, according to Sedarmayanti $(2011,260)$ is the work of employees that has concrete and measurable evidence. Performance is usually used by companies to measure their success or failure in carrying out their operational activities. If employees have poor performance, then the company's performance can also be said to be bad, but if the employees' performance is good, then the company's performance can also be said to be good. Performance itself can be influenced by factors such as compensation, organizational culture and motivation.

Most people today, work with the aim of getting paid for their work. According to Dessler $(2017,382)$ compensation is any form of payment or award given to employees and given for their involvement in the company. According to Khan and Jabbar $(2013,25)$ good compensation is able to encourage employees to work better which will affect the employee's performance.

Factors such as organizational culture are also important to pay attention to so that someone is able to produce good performance. According to Schein $(2017,6)$ organizational culture is an archetype that must be taught to all members, even new members, to act and solve problems, form employees who are able to adapt to the environment and unite organizational members. According to Gultom $(2014,177)$ organizational culture is able to reflect the values, norms and ethics in the company so that it can influence the way employees behave and interact. If the existing organizational culture is good, then employee performance will also improve.

Based on research conducted by Giantari and Riana in 2017 with the research title "The Effect of Organizational Culture on Work Motivation and Employee Performance at Klumpu Bali Resort Sanur", it was found that 
organizational culture had a positive and significant effect on employee performance, while based on research conducted by Gulo on In 2018 with the research title "The Effect of Transformational Leadership, Organizational Culture and Work Involvement on Employee Performance", it was found that organizational culture had no effect on employee performance. Thus, with the differences in the results obtained from the two researchers, a research gap was formed in this study.

Motivation is also one of the factors that can affect a person's performance. According to Robbins and Judge $(2019,249)$ motivation is a process that explains the intensity, direction and persistence of an individual in achieving his goals. Motivation will explain how a person is willing to try to achieve what he wants, how that person will work and how long it will take to maintain his performance. According to Mulyadi $(2019,87)$ when a person has high motivation, he will work hard and will produce good performance.

This research is a replication of previous research conducted by Udin Saprudin in 2018 with the title Analysis of the Effect of Compensation, Organizational Culture and Motivation on Employee Performance at the Regional Water Company Tirta Kerta Raharja Tangerang Regency. The results obtained from this study are that each of the independent variables, namely compensation, organizational culture and motivation, have a positive and significant effect on employee performance. This previous research used the object of research at the Regional Drinking Water Company of Tirta Kerta Rahaja Tangerang Regency, while for this study using the research object, namely PT. Perfect Circle Engineering. In this study, the total population used was 73 employees and the sample size was 59 employees who were permanent employees of PT. Perfect Circle Engineering and is considered to meet the criteria of the respondent.

\section{Compensation}

According to Gerhart et al. (2020, 708) compensation is all forms of payment in the form of financial and all forms of services obtained as a form of employee involvement. According to Dessler $(2017,382)$, compensation is any form of payment or award given to employees and given for their involvement in the company. According to Kadarisman $(2014,1)$ compensation is a reward that will be received by workers or employees for the work they give.

\section{Organizational culture}

According to Schein $(2017,6)$, organizational culture is an archetype that must be taught to all members, even new members, to act and solve problems, form employees who are able to adapt to the environment and unite organizational members. According to Robbins and Judge $(2019,541)$, organizational culture is the values, beliefs and assumptions held by organizational members which can differentiate the organization from other organizations. According to Sudaryono $(2014,11)$, organizational culture is a basic assumption created and developed by a group to solve problems and work well so that it is used as a perspective and thinking in the company.

\section{Motivation}

According to Mangkunegara $(2013,93)$, motivation is a condition that can encourage employees to achieve their goals. According to Daft $(2017,246)$, motivation is an impetus both from within a person and from outside which will generate enthusiasm and persistence to do something. According to Hasibuan $(2019,141)$, motivation is something that will lead to enthusiastic behavior and willingness to work hard to achieve optimal results.

\section{Performance}

According to Amir (2015, 5), performance is a process carried out by a person where the activities carried out are related to the 
assigned task. This performance will later display the entirety of the input, process, output and outcome. According to Sedarmayanti (2011, 260), performance is a translation from the English language "performance" which means the work results of employees where these results must be concrete and measurable. According to Simanjuntak $(2011,1)$, performance is the result of implementing certain tasks.

\section{Research Model}

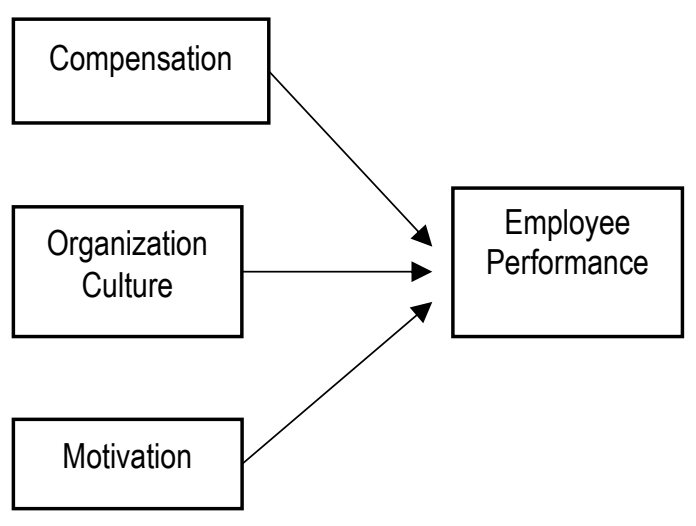

\section{METHODS}

This research is in the form of research that is causality. According to Sugiyono (2017, 64), research that has a causal relationship is research that has a relationship with causal properties. Research conducted by researchers was to determine the effect of compensation, organizational culture and motivation on employee performance at PT. Perfect Circle Engineering.

Sugiyono $(2017,136)$ states that the population is the object or subject that the researcher determines to study and draw conclusions which have certain qualities and characteristics. In this study, the total population used was 73 employees of PT. Perfect Circle Engineering.

While the sample according to Sugiyono $(2017,137)$, is part of the number and characteristics of the population. In this study, the number of samples used was 59 employees who were permanent employees of PT. Perfect Circle Engineering and is considered to meet the criteria of the respondent.

In this study, the sampling technique used one of the non-probability sampling techniques, namely purposive sampling. Non probability sampling itself is a sampling technique that does not provide equal opportunities for members of the population to be sampled. According to Sugiyono $(2017,142)$ Purposive sampling is a sample selection technique with consideration of certain criteria. Consideration of the criteria for sampling in this study, among others:

1. Have dependents.

2. Permanent employees at PT. Perfect Circle Engineering.

3. Employees at Middle Level Management and Lower Level Management.

Compensation (X1) is the reward received by employees, either in the form of money or in other forms as a form of remuneration for work that has been done by an employee.

Organizational culture (X2) is an organizational characteristic in the form of values, beliefs and assumptions held by members of the organization and serves as a guide in acting and solving problems.

Motivation (X3) is anything that can encourage enthusiasm and persistence to do something in order to achieve the desired goals.

Performance $(Y)$ is a measurable and assessable work result which displays the input, process, output and outcome associated with the assigned task.

\section{RESULTS}

The descriptions of the respondent's data in this study were divided by the researcher into several categories with different criteria, including gender, age, education and years of 
service which were obtained from the respondents' biodata.

Based on the results of research in Hypothesis 1, the sig. $0.018 \leq 0.05$ so it can be concluded that $\mathrm{Ho} 1$ is rejected, so there is an influence between compensation on employee performance at PT. Perfect Circle Engineering. Likewise the results of the $t$ test, where the results of the t count obtained were 2.429 and the $t$ table used was 2.00404. Because the results of $t$ count 2.429> t table 2.00404, then $\mathrm{Ho} 1$ is rejected, so it can be concluded that there is a significant influence between compensation on employee performance at PT. Perfect Circle Engineering.

Based on the research results, the sig. $0.319>0.05$ so it can be concluded that $\mathrm{Ha} 2$ is rejected, so there is no influence between organizational culture on employee performance at PT. Perfect Circle Engineering. Likewise the results of the t test, where the tcount obtained is 1.005 and the $t$ table used is 2.00404. Because the results of tcount $1.005 \leq$ ttable 2.00404 , then $\mathrm{Ha} 2$ is rejected, so it can be concluded that there is no significant influence between organizational culture on employee performance at PT. Perfect Circle Engineering.

Based on the results of the study the value of sig. $0.022 \leq 0.05$ so it can be concluded that $\mathrm{Ho} 3$ is rejected, so there is an influence between motivation on employee performance at PT. Perfect Circle Engineering. Likewise, the t-test results, where the t-count results obtained are 2.350 and the t-table used is 2.00404 . Because the results of tcount 2.350> ttable 2.00404, Ho3 is rejected, so it can be concluded that there is a significant influence between motivation on employee performance at PT. Perfect Circle Engineering.

\section{CONCLUSIONS}

The results of this study can be concluded as follows:
1. There is an influence between compensation on employee performance at PT. Perfect Circle Engineering. This statement is supported by the results of research conducted by Nugraha and Tjahjawati in 2017, Purbasari and Septian in 2017 and Sudarso in 2019.

2. There is no influence between organizational culture on employee performance at PT. Perfect Circle Engineering. This statement is supported by the results of research conducted by Gulo in 2018 and is inversely proportional to the results of research conducted by Purbasari in 2018 and Giantari and Riana in 2017.

3. There is an influence between motivation on employee performance at PT. Perfect Circle Engineering. This statement is supported by the results of research conducted by Rumondor et al. in 2016, Ni'mah et al. in 2017 and Yulinda and Rozzyana in 2018.

The limitations that occur during this research process can be described as follows:

1. Research conducted only at PT. Perfect Circle Engineering due to limited manpower, time and cost.

2. The number of samples in the study was only 59 respondents.

3. Limited data obtained from the object of research. This is because the data is said to be very internal in nature and confidential (confidential) so that the object of research cannot disseminate it to the public.

Here are some forms of recommendations that might be used as a reference for researchers who want to carry out further research:

1. Expanding the number and using a larger sample for use in further research, so that the results can be more accurate and more representative of the entire population.

2. In further research, it is better to expand the scope of research 
3. Adding independent variables outside the variables that have been used that can affect employee performance.

4. It is expected that further researchers will use research objects other than PT. Perfect Circle Engineering.

The following are some recommendations that can be considered by PT. Perfect Circle Engineering.

1. Compensation affects the performance of employees at PT. Perfect Circle Engineering. The existence of satisfaction with the compensation received by employees as evidenced by high performance, causes it to affect employees to work more productively.

2. Organizational culture does not affect the performance of employees at PT. Perfect Circle Engineering. Should a strong organizational culture be an archetype that is taught to all members of the organization, even new members, to act and solve problems, form employees who are able to adapt to the environment and unite members of the organization. Organizational culture is the values, beliefs and assumptions held by members of the organization which can differentiate the organization from other organizations.

3. Motivation affects the performance of employees at PT. Perfect Circle Engineering. By providing motivation in various forms, both financial and non-financial, and always giving appreciation to employees for the good work that has been done can encourage enthusiasm and perseverance to do something in achieving the goals desired by the organizatio

\section{REFERENCES:}

Amir, Mohammad Faisal. 2015. Memahami Evaluasi Kinerja Karyawan. Jakarta: Mitra Wacana Media.

Daft, Richard L. 2017. Leadership Experience in Asia. South Western: Cengage Learning.

Dessler, Gary. 2017. Human Resource Management, Fifteenth Edition. England: Pearson Education.

Giantari, Ida Ayu Indah dan I Gede Riana. 2017. Pengaruh Budaya Organisai Terhadap Motivasi Kerja dan Kinerja Karyawan Klumpu Bali Resort Sanur. E-Jurnal Manajemen Unud, 6(12), 6471-6498.

Gulo, Yupiter. 2018. Pengaruh Kepemimpinan Transformasional, Budaya Organisasi dan Keterlibatan Kerja Terhadap Kinerja Karyawan. Jurnal Bisnis dan Akuntansi, 16(1a).

Gultom, Dedek Kurniawan. 2018. Pengaruh Budaya Organisasi Perusahaan dan Motivasi Terhadap Kinerja Karyawan pada PT. Perusahaan Gas Negara (PERSERO) Tbk Medan. Jurnal Manajemen \& Bisnis, 14(02), 176-184.

Hasibuan, Malayu. 2019. Manajemen Sumber Daya Manusia. Jakarta: Bumi Aksara.

Khan M., Jabbar M. 2013. Determinants of Employees Performance in Corporate Sector: Case of an Emerging Market. "Business and Management Research", 2(3).

M, Kadarsiman. 2014. Manajemen Kompensasi, Jakarta: Rajawali Pers.

Mangkunegara, A. P. (2013). Manajemen Sumber Daya Manusia Perusahaan. Bandung: PT Remaja Rosdakarya offset.

Milkovich, George, Jerry Newman dan Barry Gerhart. 2020. Compensation, Thirteenth Edition. New York: McGrawHill.

Mulyadi, Prayogo Wicaksono. 2019. Pengaruh Motivasi Dan Budaya Organisasi Terhadap Kinerja Karyawan Pada PT. Fenixindo Global Mandiri (Veneta System). Jurnal IImiah Manajemen Sumber Daya Manusia, 3(1), 85-98.

Purbasari, Niken Rr. 2018. Kontribusi Budaya Perusahaan dan Moral Kerja Terhadap Kinerja Karyawan. Jurnal Bisnis dan Akuntansi, 14(1), 1-16. 
Purbasari, Niken Rr. dan Septian T. A. 2017. Factors Influencing On Employee Performance of Production Departement on the Manufacturing Food Industry in Indonesia. Polish Journal of Management Studies, 16(2).

Robbins, Stephen P dan Timothy A. Judge .2019. Organizational Behavior, Eighteenth Edition. USA: Pearson Education Limited.

Saprudin, Udin. 2018. Analisis Pengaruh Kompensasi, Budaya Organisasi Dan Motivasi Terhadap Kinerja Pegawai Pada Perusahaan Daerah Air Minum Tirta Kerta Raharja Kabupaten Tangerang. Jurnal Madani, 1(1), 267286.

Schein, Edgar dan Pieter Schein. 2017. Organizational Culture and Leadership. New Jersey: John Wiley and Sons. Sedarmayanti. 2011. Manajemen Sumber Daya Manusia, Reformasi Birokrasi Manajemen Pegawai Negeri Sipil. Bandung: Rafika Aditama.

Simanjuntak, Payaman J. 2011. Manajemen dan Evaluasi Kinerja. Jakarta: Lembaga Penerbit Fakultas Ekonomi Universitas Indonesia.

Sudaryono. 2014. Budaya dan Perilaku Organisasi. Jakarta: Lentera IImu Cendekia Perkantoran Sentra.

Sugiyono. 2017. Metode Penelitian Bisnis Pendekatan Kuantitatif, Kualitatif, Kombinasi dan R\&D. Bandung: Alfabeta. 
